\title{
Gray Zone Theatre Dissidence: Rethinking Revolution through the Enactment of Civil Society
}

\section{Dennis C. Beck}

While the impetus for change in the late-communist Soviet Union came from above, its source in East-Central Europe, as Barbara Falk notes in Dilemmas of Dissidence, lay elsewhere. ${ }^{1}$ That elsewhere was below, from civil society. Falk credits East-Central Europe's dissident writer intellectuals after 1968 for theorizing in the (post)totalitarian context the formation, function, and possibilities of what they called the parallel polis, second society, or counter-public sphere. ${ }^{2}$ Nevertheless, isolated from the broader population and barred from publishing, the writer-dissidents' influence on the population, particularly in Czechoslovakia, was limited. A small group of Czech theatre artists, however, functioning as organic intellectuals in the Gramscian sense, developed ideas that paralleled and often preceded those of the writers, from whom they were effectively isolated for a decade by their suspect position in official, state-supported theatres. They not only developed the framework for what civil society could accomplish but, moving beyond the writers, explored in a detailed, practical, and dramaturgical way how it could be engaged, influenced, and finally imagined as having a national identity in contrast and opposition to the state. Their means of doing so despite official status and the public nature of their art constitutes a poetics and "antipolitical" politics of authorial theatre.

Civil society, argues Michael Walzer, designates "the space of uncoerced human association and also the set of relational networks - formed for the sake of family, faith, interest, and ideology - that fill this space." ${ }^{3}$ Unlike Hungary, where elements of a free market and semi-independent organizations effectively depoliticized society and demobilized intellectuals, or Poland, where Solidarity and the Catholic Church created organizational space for independent initiatives to develop, Czechoslovakia lacked the kind of organizational, institutional, and semi-independent terrain that afforded traditionally defined civil society space to grow. The 1968 Warsaw Pact invasion of Czechoslovakia brought with it a new, neo-Stalinist government that sought to "normalize" society through Party purges,

\footnotetext{
Dennis Beck's articles on Czech theatre, acting, and design, and theatre's social efficacy have appeared in Theatre Journal, Theater, Theatre Survey, Theatre InSight, Slavic and East European Theatre, Toronto Slavic Quarterly, Theatre Design and Technology, and the anthologies Method Acting Reconsidered and To Teach / To Study Theatre at University: What for?, and Theatre and Performance in Eastern Europe: The Changing Scene. His current book project, Stages of Revolution: Czech Alternative Theatre, 19681989, explores the development, dramaturgies, and historical significance of pro-democratic theatres in communist Czechoslovakia and their pivotal role in the "Velvet" Revolution. He serves as theatre area coordinator of James Madison University's School of Theatre and Dance.
} 
measures to induce compliance by individuals, and banning of cultural works. Such actions, notes political historian Robin Shepherd, resulted in an "atomization which accompanied the destruction of civil society." Unlike in Poland, all theatres were made legal, subsidized entities of the state. Nor did gaps allow underground theatre, to which Polish churches provided safe havens. ${ }^{5}$ In the 1970 s Czechs attempted to establish a few fully independent underground theatres in homes ("apartment theatre") with tiny audiences, but the regime quickly located and terminated them. ${ }^{6}$ Writers with an independent propensity found their work banned, their movements and communications surveyed, their children denied higher education, and their livelihoods reduced to stocking boilers and collecting trash. Freedom of assembly and association was limited to twelve or fewer persons without a special permit.

These conditions meant that the "gray zone," which flourished in other countries, was difficult for outsiders to discern in the Czech lands. Robin H. E. Shepherd recalls that Czechoslovakia had "one of the most orthodox and efficiently organized of the region's totalitarian regimes," a consequence of which was "the absence of any independent organizations, the absence even of organizations existing under severe constraints." Rather than being comprised of formal groups, the Czech gray zone was "made up largely of individuals acting within their own limited capacities." Such individuals' hearts and minds were with the dissidents, but their lives and livelihoods continued in the system. People of divided allegiances could not be trusted by dissidents who had dared to challenge the regime and for whom the stakes were high. Over the next decade, however, playwright Václav Havel, whose outspokenness had transformed him into an influential dissident, would change his perspective due primarily to theatre he witnessed.

Since Czech dramaturgy, which had carried the torch of socio-political critique, was "silenced" (in the words of Marketa Goetz-Stankiewicz) by the new regime, an emerging trio of theatre companies created their own texts and seldom used previously written plays. ${ }^{9}$ Whatever their source, their artists claimed full authorship and responsibility for the statement of the performance. Their theories and techniques were designed to evade the authorities' control of authorial processes, influence on their productions, and ability to censor or, in a sense, even define their work. Nonetheless, as each new theatre applied for and was granted professional status, it accepted with funding the onus of government oversight. They became, therefore, institutions with designated performance spaces whose artists, like their audiences, negotiated the gray zone's conflicting demands of personal conscience and the public, regime-controlled sphere. With the absence of independent organizations, restrictions on freedom of assembly, criminalization of organized oppositional activity, and sequestering of popular dissent into the private sphere, these authorial theatres provided the only physical gathering spaces for citizens concerned with their loss of freedom, pluralism, and dialogue within the socio-political environment. By reclaiming "islands" of social 
space for independent expression, they emerged as the primary public home of the gray zone and civil society. As such, they created the sole environment prior to the 1988-1989 demonstrations in which civil society could be experienced rather than merely theorized or imagined.

Like tipping points that release tectonic pressure, the political earthquakes of the falling Berlin Wall and "Velvet" Revolution moved massive states into alignment with national societies whose collective desires and identities had previously shifted. Although dissidents expected political changes to develop as a result of erosion rather than explosion, events of 1989 nonetheless validated their twenty years of re-theorizing revolution. The commitment eventually demonstrated and earlier professed by Mikhail Gorbachev not to interfere militarily in the USSR's satellite states allowed for developments within them to take an internally defined course. ${ }^{10}$ The USSR's 1968 military termination of Czechoslovakia's endeavor to reform a "universal" (read "Soviet and imposed") form of communism into a regionally appropriate "socialism with a human face" had proved to citizens around the Bloc that attempts to reform communism internally were a dead end; revolution from outside the party would be the only path to effective political transformation. With the violent examples of the Bolshevik and French Revolutions as inverse guide and the USSR's overwhelming military force as deterrent, dissidents re-conceptualized violent revolution as the formation of "bacteriological weapon[s]" of parallel polei. Falk calls these polei "islands of freedom," recalling dramaturg Petr Oslzlý's description thirteen years earlier of the alternative theatres as "islands of relative spiritual freedom." to which states would be compelled to respond, therefore, was not the state but society, argued Polish dissident Adam Michnik, and, particularly, the individuals that constitute it. In order to affect the behavior and association of individuals, the revolution would be one of consciousness. ${ }^{12}$ In this spirit, Czech alternative theatre artists functioned as organic intellectuals, i.e., as participating members rather than removed observers of their society who, through culture and language, articulate and "direct the ideas and aspirations of the class to which they organically belong." 13 Examination of the development of such artist-intellectuals' dramaturgy as theorized and practiced reveals the complex and changing relationship it held to the evolution of the writer-dissidents' concepts of civil society, its artists' unique ability to put such ideas into microcosmic practice, and their sensitive dance with civil society as its simultaneous leader, follower, and participant. Over time, they struggled to impart to that society an increasingly national identity without falling into the nonpluralistic tendencies of a xenophobic nationalism that would replay the monism of the totalitarian system they opposed. In that effort, as well as their more general attempt to overcome the isolationism of Cold War policies and paranoias, dissident intellectuals of all stripes synthesized foreign (global) influences with local concepts and traditions. Their incipient and conscious transculturalism provided Czechs an 
early experience of a world of plurality, one that would eventually shatter familiar binaries when the communist era came to a crashing halt.

Czechs themselves repeat the words "shock" and "distrust" to describe the initial years of "Normalization"(1969-1973): shock because their liberal government became suddenly neo-Stalinist and no one could accept the change as permanent; distrust, not only because the state became punitive and unpredictable, but because distinguishing informers from amongst one's acquaintances became nearly impossible. "It is not enough to say that there is no freedom of assembly under totalitarianism," noted one Czech dissident speaking anonymously. "Totalitarianism knows no worse protagonist and is harshest of all in repressing all human associations." Therein lay much of the threat posed by the authorial theatres: they introduced an oasis of voluntary association over topical concerns within a civic desert where "people are not allowed to know each other and associate on the basis of their own decision." "It It would not be until 1972 that the first of the banned writers' self-published samizdat writings appeared, circulating at that time primarily amongst the newly labeled "dissidents." Theatre, in contrast, reached the general public, and the distinct attraction of the authorial theatres lay in the torch passed in the public arena from the writers to theatre artists: authorship.

Although the roots of authorial theatre reach back to Czech interwar avantgarde experiments and postwar "small forms" style, the reclamation of non-verbal/ non-textual theatrical art and its sources, observes Josef Kovalčuk, began as a distinctive and conscious trend amongst new studio theatres in the early seventies. ${ }^{15}$ The regime's attempted and largely successful silencing of authors underscored the significance and power of authorship in the new context. The implications of asserting authority in conditions of political authoritarianism form the philosophical foundation for a "poetics" of authorial theatre as well as a basis for the coalescence of a civil society. The "authorship" of this theatre underscores a quality latent, if under-tapped, in all theatre, one that theorist Alan Read discusses as central to an ethics of theatre:

Theater that is unwritten, that is beyond the scriptural economy in the black market that is the everyday, relies on a "saying" rather than the "said". The said is the discourse that is translatable, transferable, and performable. The saying is the speech act itself that resists removal from its context however banal that arena might be. Saying replaces the inert object of literature and language with the process of enunciation, as words which remain the property of users. . . Saying is more than speaking, it is a way of giving everything, of not keeping anything for oneself, and here embraces and challenges the politics of quietude. ${ }^{16}$ 
By devaluing the "said" of theatre and shifting the "saying" into a primary position, authorial theatre artists assumed full responsibility for their "statements" and performance texts. Not only did improvisation inform their process, but they initiated the authorial function in the very method of arriving at their performance text, which began not with sources but with deliberation on the theme that needed "saying." Only once it was excavated were sources located that amplified and provided space within which to explore it. A central motivation of and concept inherent to this approach, therefore, is that of responsibility.

Authorial artists developed, deepened, and utilized their principles increasingly strategically over time. In response to a mode of theatre production in established theatres that reflected the hierarchy of the communist party-state, the authorial theatres made collaboration and collective creation a cornerstone of their work. Recognizing that the structure of a theatre supports or inhibits collective work, they eliminated hierarchies so that all communication was direct. Multiple levels invite miscommunication and attenuate any sense of community, agency, and common purpose. Theatre Goose on a String (Divadlo Husa na Provázku), for instance, based its 1970 plan, formulated as "normalization" was being implemented, on an analysis of cybernetic and information theories of MIT's Norbert Weiner and IBM's organizational model, which, with 80,000 employees, still held to three levels, fewer than that of the typical Czech theatre. ${ }^{17}$ Such "foreign" ideas were an incipient answer to the dissident question, articulated by Polish writer György Konrád in Antipolitics (1983): "How can we strengthen the horizontal human relationships of civil society against the vertical human relationships of military society?"18 Authorial artists understood the political significance of organizational and societal structure as reinforcing or impeding democracy and pluralism.

Collaboration between directors and set designers was a central principle of the Action Design utilized and developed in the authorial theatres and applied to each kind of designer, their work as a team, the development of their ideas in concert with the performers, and their relationship to audiences. ${ }^{19}$ One of the earliest of many methods of collective creation authorial theatre utilized, articulated by Studio Ypsilon, was that of play, as in the sense of "to play with" (hrát si) rather than "to play" or impersonate in a direct, unmediated way (hrát):

Theatre as collective play [playing with] is unthinkable without collective consciousness emerging from collective thinking that is a premise of a collective mode of creative work. ... Self-play of an individual and self-play of the collective is developed by a method of collective improvisation which assumes a collective mode of creation that follows from collective thinking, which is unthinkable without the collective consciousness that theatre is collective play. ${ }^{20}$ 
Like other authorial concepts, Jan Schmid's assertion that the nature of theatre itself is anti-authoritarian shares a central motivation with Jerzy Grotowski's, an attempt to return to theatre's roots and essences and to extrapolate ways of creating distinctive, "authentic" theatre from them. This motivation, identifiable in the West as well, assumed particularly political valence in the Soviet Bloc. Writing in 1964 and at that time unaware of theatrical experiments in Poland, Schmid's perspective can be seen as an original but related reaction to the same party-state system viewed as imposed and thus artificial. In Ypsilon's play as well as other manifestations, such as HaDivadlo's (HaTheatre) group creation of texts or actors' playwriting, Goose on a String's group assemblage and projects, or in the authorial theatres' active relationship to audience members and numerous joint productions and projects, collective creation constituted a denial of and alternative to the monistic system as well as a recognition of human equality. Moreover, it provided everyone a chance to speak ("say") and to experience ownership of the group's creation. Thus, ironically, it reflected the Marxist idea of ownership of the means of production and empowerment of the average worker-citizen, serving as an implicit critique of how far the regime's practice diverged from its expressed beliefs, and highlighting the illusion on which the state depended to prop up its claims to legitimacy. ${ }^{21}$ Unlike stereotypes of communism promulgated by the regime in which individuals willingly sacrificed their own views and desires for (the good of) the group, authorial theatres utilized and honored the individual personalities and views of its performers, who often performed beside, juxtaposed to, or playing-with their characters, ${ }^{22}$ presenting a "picture of the world" in which individual attitudes to topics and themes play a vital role. Negotiating the dialectic between the collective and individual, due to the social nature of theatre, may come more easily to its artists than to others. Not until late 1976 did writer-dissidents realize the potential power of collective creation. With no single author identified, 243 signed Charter 77, dated 1 January 1977, which held the Czechoslovak government accountable for infractions against the human rights provisions to which it had signed in its constitution, the Helsinki Accords, and United Nations covenants. Although the authors carefully defined it as "not an organization" but rather "a loose, informal and open association of people of various shades of opinion, faiths and professions united by the will to strive individually and collectively for the respecting of civic and human rights in our own country and throughout the world," "Charter 77" continued to issue declarations and reports for over a decade..$^{23}$ As importantly, writers had begun to exchange their texts, and in their call for formation of a parallel polis as an alternative public sphere in the following year, they articulated that the project of nurturing civil society was a collective effort.

The principle of pluralism and the openness of the stage creation affected the theatres' work in a number of different ways. The incorporation of multiple voices 
and points of view extended not only to a work's creators but to the sources of the work itself, its reception and relationship with an audience, and acting theory. The principles of montage from a plurality of sources and perspectives guided authorial theatre's approach to text and staging. While the simplest kind of montage connects pieces into a unit, as in cabaret or vaudeville, authorial theatres used a method with richer possibilities by synthesizing its principles with fabulation (plot-construction). In their work, "fabulation becomes a bearer of causal connections and of historical succession; montage on the other hand bears meanings which are outside of the ordinary, logical course of the action, and its associative connections can invoke the emotional and irrational — hidden mysterious connections," observes Czech scholar Zdeněk Hořínek. Within the post-totalitarian context the implications of its basis in "the changing of viewpoints and perspectives, and in the pluralities of seeing and evaluating reality" were multiple. Montage denied the closure of meaning; tactically, in concert with metaphor, montage foiled communist authorities' attempt to prove any particular ideological or anti-regime intention. For the spectator, it called upon him or her to act as the agent of the synthesis of fragments, the site of the "final stage, in which hints are joined together and thereby new ideas are composed-ideas applied according to personal experience." ${ }^{24}$ Synthesizing afforded the spectator an experience contrasting to nearly all others in the public sphere and media, where authorities sought to delimit and determine meaning. In the assembly of meaning, authorial audiences found themselves treated as equals and adults, individuals and free agents. Nevertheless, montage did not "infinitely defer" meaning since a Stanley Fish-like interpretive community gathered around the shared experience of historical events and alternative theatre's onstage attempts to define communal values, not as detached observers but as organic members of their local communities. Toward that end, not only did authorial theatre artists create methods of "feedback" with audiences (surveys - officially banned except by sociologists - direct dialogue with spectators, mini-interviews by coat-check personnel, etc.), but, in contrast to most American and Czech "stone" theatre actors, they lived as their audiences lived — raising families, going to pubs, riding busesin order to sensitize themselves to predominant currents. Sergei Eisenstein — only one of the NEP-era Russian theorist-practitioners of which authorial artists made conscious use - in his influential essay on montage explains that "[W]hat is juxtaposed is not phenomena but chains of associations connected with the given phenomena for the given audience." ${ }^{25}$ Montage, therefore, depended upon and could help foster community by prompting an audience into communal self-recognition through revelation of its shared understandings and associations. Czech scholar Vladimír Jindra recalls that montage scenic design, for example, created "a reality which would be a topical interpretation of the subconscious of a generation and an expression of an epoch." ${ }^{26}$ Audiences perceived, sensed, and confirmed collective meanings through the reactions of others (an active experience of community that 
reading dissident literature did not admit) and generally understood signifiers. Thus, the mode of theatrical production in conjunction with particular themes and images served as one of the strongest authorial means of consolidating a community of shared understandings about its situation, identities, beliefs, and possibilities. Within and through such micro-cosmic experiences, the contained space of authorial theatres offered individuals a lived sense of civil society. Post-show conversations, the knowledge that their local theatre company toured to other places around the country, and the recognition of familiar sentiments in productions from companies hosted by their own theatre had a communally expansive effect. Audiences became aware that the communities of which they had felt a voluntary and organic part during the performance existed on different and not so distant islands. Plurality and openness of the performance text would be, therefore, inextricable from another authorial principle: theatre as a creation of and self-recognizing agent for community.

Not until late in the 1970s would the dissidents articulate the significance of such experiences in writings influenced by Czech philosopher Jan Patočka. Most important amongst these was Havel's 1978 essay "The Power of the Powerless," often recognized as "the single most-important theorization of the dissident movements in East-Central Europe prior to 1989." ${ }^{27}$ For both Patočka and Havel, "human responsibility involves the affirmation of choice and action." Patočka asserted that individuals can "transform themselves from passively accepting 'fate' into freely and actively 'choosing' destiny. . . . The ability to act constitutes history." Critically, therefore, "freedom was not conceived of as liberty or volition, but as initiative." Far from depending on the qualities or capacities of an individual, however, such freedom is "based on the existence and freedom of others." 28 Dissidents like Václav Benda would therefore advocate the creation of a parallel public sphere, the model for which he saw already existing in the realm of culture. ${ }^{29}$ The "pursuit and exercise of freedom," which Czechs had attempted to free from the risks of public disclosure in the safety of the private realm, demanded, as the authorial theatres provided, "public space and a conversation among citizens." ${ }^{30}$ Community activated and exercised freedom and responsibility for one's initiative. The risks inherent in the public sphere tested and made actual one's choice to live freely.

Montage principles provided not only opportunities for the experience of community, interpretive freedom, and individual responsibility but an alternative to the logical and causal driving of traditional plot toward an author-determined resolution. It could, Hořínek noted, "invoke the emotional and irrational-hidden, mysterious connections." Ypsilon, recalling but not daring to reference American John Cage's experiments, employed the irrational through the incorporation of chance and non-intentionality. The riskier direction, however, lay in a different definition of mystery. In two ways, authorial theatres expressed belief in a power beyond that of any government. HaDivadlo produced works influenced by German 
and Czech expressionism that were highly atmospheric, non-representational, and subjective. They were often called "grotesques" by reviewers and revealed the actors in an extremely personal, familiar way while simultaneously placing them in archetypal roles that suggested, through elliptical and sparse speech, juxtaposed fragments, and stark but cryptic images, a reality beyond the material.

More brazen thematically in its assertion that values worth living by must be based on commandments issuing from beyond the worldly and rational, Goose on a String dramatized Jan Amos Comenius's The Labyrinth of the World and the Paradise of the Heart, a call to reorient the "paradise of the heart" to conscience and spiritual belief, and to beware the seductions of the world. This morality play raised the issues that concerned Havel when he wrote in 1977 that "a person who has been seduced by the consumer value system . . . and who has no roots in the order of being, no sense of responsibility for anything higher than his or her own personal survival is a demoralized person." He implicated the totalitarian system in fostering this demoralization. ${ }^{31}$ Ypsilon had introduced a variation on this theme as early as 1975 with Thirteen Aromas, in which the values and idealism of 13-year-old Maruška contrast with the cynicism, compromises, and fatalism of her parents' generation in Nazi-Protectorate Czechoslovakia. It "made the sting of analysis of the Czech national character sound for the first time, lashing as cruelly as deskinning our conscience, whipping our thinking and especially our indifference and complacency." 32 Authorial theatres did not anticipate all of the ideas in Havel's 1978 essay, but three years prior to it they had registered the fundamental perception that the rejection or relegation of conscience to the private sphere while abandoning it in the public was a communal problem that paralyzed the "nation" in the face of externally identified state power.

Havel's solution was "living in truth," by which he meant "any means by which a person or group revolts against manipulation," including signing letters, attending oppositional cultural activities, etc. As "humanity's revolt against an enforced position, [it] is . . . an attempt to regain control over one's own sense of responsibility. In other words, it is clearly a moral act." ${ }^{33}$ Not until his 1984 essay "Politics and Conscience" would Havel specify the origin of that morality, conscience, and responsibility. By then, the relationship between the authorial theatres and dissidents had grown more intimate, with Havel attending performances and Goose on a String producing dissident Milan Uhde's plays as "collective creations." Labyrinth of the World opened in June of 1983, a few months after Havel left prison and penned "Conscience." It expressed, in light of humanity's abuse of the natural world, the need to honor

something beyond its horizon, something beyond or above it that might escape our grasp but, for just that reason, firmly grounds this world, bestows upon it its order and measure, and 
is the hidden source of all the rules, customs, commandments, prohibitions, and norms that hold within it. The natural world, in virtue of its very being, bears within it the presupposition of the absolute which grounds, delimits, animates, and directs it, without which it would be unthinkable, absurd, and superfluous, and which we can only quietly respect. ${ }^{34}$

In place of personal responsibility that stems from recognizing the Absolute or Absolute Horizon, rejected as "subjective illusion" by modern systems, humanity has accepted "the fiction of objectivity stripped of all that is concretely human, of a rational understanding of the cosmos, and of an abstract schema of a putative 'historical necessity" " that will achieve "universal welfare." Impersonal power and the automatized systems that perpetuate it in the labyrinth of the world (i.e., posttotalitarianism and Western rationalism) lead "Man" to deny "his personal "preobjective' experience of the lived world, while relegating personal conscience and consciousness to the bathroom, as something so private that it is no one's business." Such a division of the public and private, which leads individuals to live a lie, and which he diagnosed as creating a crisis of identity, could be overcome by resisting "vigilantly, thoughtfully and attentively, but at the same time with total dedication, at every step and everywhere, the irrational momentum of anonymous, impersonal and inhuman power - the power of ideologies, systems, apparat, bureaucracy, artificial languages and political slogans." ${ }^{35}$ A key step in healing these personal and social wounds and recreating the lost function of now banned critical journals, books, and occasions for public discussion "through which society becomes aware of itself" lay in reclaiming public space for "subjective preference and private feeling," the individuality of individuals, and the expression of conscience as a public act. Here, indirect though they seem, the intense, enigmatic subjectivity of HaDivadlo's dimly lit performances, Goose on a String director Eva Tálská's evocatively imagistic dramatizations of poetic works, and the publicly recognized personality of the Ypsilon actor co-existing with the role nonetheless re-introduced space for social self-awareness into Czech society. Their increasing sense of personal testimony, in works like the co-production Cesty (Journeys/Paths, 1986), which expressed four ensembles' collective and personal experiences and perspectives over eighteen years of communist rule, widened the space further and began to act as an invitation or challenge to audiences not unlike Havel's in "Conscience": "We must not be ashamed that we are capable of love, friendship, solidarity, sympathy and tolerance, but just the opposite: we must set these fundamental dimensions of our humanity free from their 'private' exile and accept them as the only genuine starting point of meaningful human community. ${ }^{" 36}$ Daring to express the personal within public space not only begins to build the trust that enables community but 
also shifts individuals into the position of subjects.

Within the authorial and dissident framework, subjectivity holds two connotations, both of which express and are informed by the idea of authenticity. On the authorial stage, to present one's viewpoint, values, and individuality was also to assert one's agency, to reject impersonal power's capacity to define the self, and to place trust in those witnessing such revelations not to denounce them. In the exclusively private sphere such assertions of individuality would make no sound. "This retrieval of subjectivity is profoundly social," Falk notes of lessons learned by Central European dissidents: "it cannot be an interior existential experience but requires ongoing solidarity and open-ended responsibility for others and the multiple publics in which we locate our identities." Performances of and increasing space for independence in the public realm, believed György Konrad, irrespective of any particular ideology, creates an "antipolitical" deterioration of a political system and inspires "greater independence of private thought, in the imagining of alternatives. Citizens are more likely to view themselves and each other as participants and subjects, and separate themselves from the party-state." ${ }^{37}$ In order to earn the trust of citizens, however, performers of the self, contenders of individuality, needed to offer a presentation that could be accepted as authentic. Therefore, authorial theatres stripped away and deconstructed illusion. Each theatre delineated actor from character, but this method alone fails to guarantee that the actor presented is not the character of an actor; therefore, companies introduced various kinds of testimony as a component of performance, ranging from casual banter with audiences as the actor links a comment by her character to an item in the day's news, to asides, to conversation with audiences following performances, to personal items onstage. Testimony constituted the basis for many performance texts, overtly as in Cesty, or embedded in a "fiction" that paralleled the artists" experiences, like HaDivadlo's Fragments of an Unfinished Novel. Beneath even the most fictitious pretexts, however, testimony grounded the theatres' work as integral to their authorial approach.

The physical design of the performance also played a role in undermining the illusion and lies that the public associated with the regime. Not only were authorial spaces intimate, with easy and frequent intercourse between stage action and audience areas, but the fourth principle of Action Design could be applied to every aspect of production:

$[\mathrm{N}]$ o matter how many meanings might be attached to the setting as it interacts with the text, director, and actors, the objects onstage never deny their reality — as both concrete objects and purposefully theatrical materials used in the fictive construction. Coupled with a personal and complex metaphoric structure, Action Design frankly admits actuality. It is through such irony 
that this theatre approaches "reality," for irony not only enables a vital self-reflexivity for both artists and audience, but allows us to see ourselves with humility and humor. ${ }^{38}$

Many of the costume pieces HaDivadlo actors used, for example, recurred from role to role and were, in fact, the actor's personal clothing, which many audience members would have seen on them in their daily lives. These "working clothes" emerged from the basic personality of the actor and formed part of the actor's "signature" in the same way as did the voice and yet expressed their archetype as well. ${ }^{39}$

The central "actuality" of the performance, however, was always the actor as individual, reflecting and anticipating dissident ideas on the central importance of authenticity. Patočka proposes that perceiving the predicament of trying to free oneself of conformity to ideas and styles that nonetheless form the matrix of our thought is the first step toward discovering and taking responsibility for an authentic existence. Even more than Patočka, Havel would adopt a Heideggerian view of responsibility but instill it with a moral dimension. Referring to the predicament of being born into a world where ideas and ways of life are already given and decisions in our lives are made essentially by internalized cultural forces individuals rarely notice, Heidegger proposes that " $[\mathrm{t}]$ his process can be reversed only in such a way that Da-sein [the being for whom being is a question] explicitly brings itself back to itself from the lostness in the 'they.' But this bringing-back must have the kind of being by the neglect of which Da-Sein has lost itself [we have lost ourselves] in inauthenticity." 40 "Living in truth" for Havel, therefore, can be aided by those organs of social self-awareness that juxtapose the authentic and inauthentic in ways that allow individuals to discern the basis of their conformity. Because authentic being 'is lost in the 'they,' it must first find itself. In order to find itself at all, it must be 'shown' to itself in its possible authenticity." ${ }^{41}$ For Havel, such authenticity entails the moral responsibility to live in accord with the non-negotiable values of human dignity, free expression of beliefs, accountability for self and community, etc. Dissent, therefore, cannot be private but is necessarily extended to the "public space of the agora." ${ }^{42}$ In Havel's example, the greengrocer who refuses to place the expected pro-communist sign in his window has performed a "transgression [that] is a genuine denial of the system," thus revealing the basis of conformity, throwing the conformity of others into relief, and challenging his fellow citizens toward a similar authenticity. ${ }^{43}$ His choice constitutes his being-in-the-world, his re-creation of authentic existence and thus, as Patočka would assert, his freedom. In the public space of performance, alternative theatre actors replayed the greengrocer's role.

The greengrocer's choice, of which the themes and modes of authorial production stood as collective examples, contained more, therefore, than an existential significance, which Havel calls "returning humanity to its inherent nature," or a "noetic dimension (revealing reality as it is), or a moral dimension 
(setting an example for others). It also ha[d] an unambiguous political dimension." ${ }^{44}$ The "fundamental threat" of living and performing in truth to the system was the revelation that it was built on lies, one of the most central being the fiction that the Prague Spring was a counter-revolution mounted by elements hostile to the wellbeing of the nation and aided by foreign agents. ${ }^{45}$ Its conflation of nation and state defined writers with a critical voice as dissident, oppositional, and "synonymous with the word "enemy"." 46 Though rarely mentioned, the regime isolated them from the general population, defining them and their ideas as fringe elements, whereas Havel observed that "the dissidents are really saying nothing other than what the vast majority of their fellow citizens think privately." They constituted, in fact, "the less radical, more loyal, and more peaceful segment of the population." Havel never clarifies, however, the object of that loyalty. On one hand, he makes repeated reference to Central European traditions of thought in contrast to the tradition that gave rise to the totalitarian state; on another, he posits the restoration of "human rights, human dignity, and civic freedom" as a fundamental precondition to any workable solution. ${ }^{47}$ Although such distinctions belong to a larger dissident project to define a distinct Central European identity, ${ }^{48}$ they were also read within the Czech context as a code for a lost Czechoslovakia. Specifically, they evoked a time when its state reflected the will of its nations, such as the interwar First Republic, when Czechoslovakia had the only democratic form of government in the region. Democracy, therefore, had its universal Greek as well as local historical associations.

Fearful of the effects of xenophobic, "illiberal" nationalism, Havel avoided references in his political essays to the Czech nation or national identity. His 1990 embrace, nevertheless, of the Czech maxim originally articulated by Czechoslovakia's first president, Tomaš Garrigue Masaryk in 1918, "věc česka je věc lidská" (the Czech concern is a human concern), ${ }^{49}$ reflects two simultaneous claims about the construction of national identity: that Czech identity is not, or should not be, founded on ethnicity but on "universally" recognized values, and that the struggle of the Czech nation is the struggle of humanity to free itself from forces that would define it as less than human. If there were ever any question where that self-defined liberal nation had stood in relation to its communist state, Havel answered by concluding his first address as president of the Czechoslovak people with a paraphrase of Masaryk's opening statement to his newly created compatriots: "People, your government has returned to you!"

Havel's celebratory announcement was the climax of a project first and primarily defined by the authorial theatres. Dissident Václav Benda in 1977 had posited the parallel polis as a strategy to lead the "obec" (community, body politic) out of "the blind alley we are in today." Unique among Soviet Bloc thinkers, Czech dissidents conceptualized an alternative society with conscious reference to ancient 
Greek models. Patočka's Platonism led them to adopt the Socratic interpretation of the Delphic oracle, that to know oneself necessitates an awareness that this task involves seeking knowledge of the whole. Patočka's incorporation of Plato's "care of the soul" stressed a necessary investigation into truth, personal demonstration of living in truth, and "the creation of a community in which truth and justice are possible." ${ }^{150}$ Seeking to make the theoretical practicable, Benda invoked the Greek polis as an authentic locus of political and democratic community that could serve as a model for a modern alternative politics and independent civil society. Once that society had reclaimed its state, its president, Havel, was fittingly hailed by non-Czechs as a Platonic philosopher-king. ${ }^{51}$ Benda, Havel, and other influential dissidents avoided references to nation, however, and framed questions of the rights of individuals and society largely in terms of universal human rights until the 1988-1989 demonstrations, all of which were called on national anniversaries. ${ }^{52}$

By 1989, Czechs had come to see the 1948 communist "coup d'état" as "yet another loss of sovereignty for the Czech state," meaning that the "Velvet" Revolution was experienced by Czechs, in fact, as a "nationalistic revolution." 53 Although Charterists referred to the government's violations of articles within the Czechoslovak constitution, implying a division between the state and the people it purported to represent, it was the authorial theatres as early as 1973 that posited the regime as analogous to the Nazis who had once occupied the country, defining Czechoslovakia's government as foreign and hostile to the well being of the Czech people and unrepresentative of a rightful configuration of its state. Goose on a String's Theatrum Anatomicum dissected the body, soul, and story of Rudolf Höss (not to be confused with Rudolf Hess, Hitler's deputy), who managed Auschwitz and "improved" the methods of extermination there. Ostensibly, the piece critiqued an official state enemy, Nazi Germany, creating a catch-22 for censors who could see that audiences read the piece analogically. Authorial theatres used the metaphor of unjust and/or foreign rule, (Nazi, Austrian, Chilean, Czarist, Mafiosi) in subsequent productions, but developed their presentation and questioning of national identity in a number of increasingly complex, surprisingly ambivalent directions. Thirteen Aromas, discussed above, not only posited an "other" but began a trend of turning the instruments of dissection on Czech historical figures and national character. HaDivadlo's Mysterious Characters revealed the honesty and bravery as well as cowardice and self-serving nature of various Czech historical figures personified by the actors as stone or bronze monuments brought to life. A recurrent strategy of such presentations was to separate received myth from historical record, to take a sobering look at Czech tendencies not only to strengthen a positive sense of national identity but also to warn of the pitfalls when it diverged from its most noble sentiments. The apogee of this trend was String's The Barterer and the Bartered, which considered the destiny of Karel Sabina, librettist of the opera The Bartered Bride by Bedřich 
Smetana, ardent Czech pro-nationalist during the period of national revival in the nineteenth century, and eventual traitor to the Czech people and collaborator with Austro-Hungarian authorities. It declined to answer the deepening questions it posed of morality, loyalty, and personal responsibility through images of Sabina's entrapment by a government that would stop at nothing to portray dissenters to its aims as traitors to the republic, and, if that failed, betrayers of the nation the dissidents professed to defend.

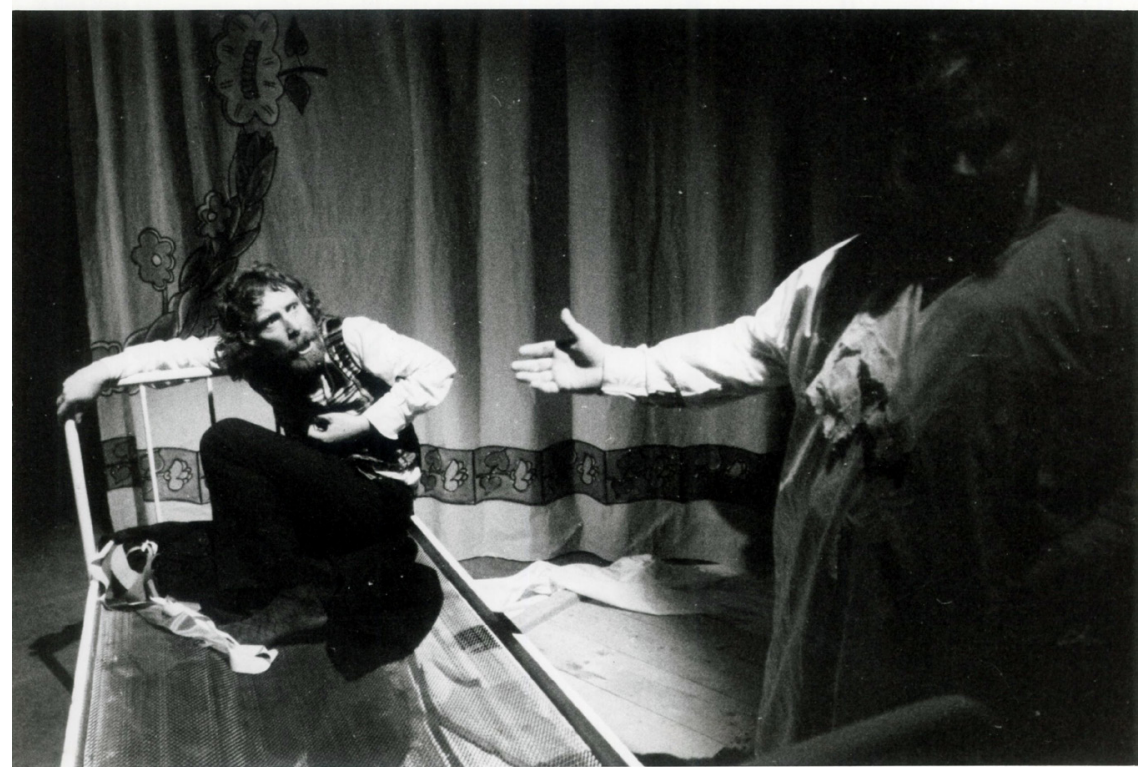

Fig. 1. Karel Sabina (played by Petr Oslzl ý) reacts to an Austro-Hungarian official's offer of help. Divadlo Husa na Prov ázku 1987 production of Prodaný a Prodaná (The Barterer and the Bartered). (CVladislav Vaňák).

Evidence suggests that authorial theatres prompted Havel's reconceptualization of the parallel polis and the civil society it represented in terms of national identity. Perhaps most influential was the authorial theatres' use of the Czech past to reconsider national values and beliefs as they were formed in critical historical moments. ${ }^{54}$ Goose on a String's 1979 co-production of Springtide of Nations with the Polish company Theatre 77 was one of the most ambitious and, consequently, most targeted for persecution by the authorities. The piece featured a number of historical speeches made by representatives of nations at the pan-European congresses of 1848 demanding release from their governing foreign states. It asserted the right of self-determination, demands for civic freedom, and the need for justice, paralleling modern efforts by Charter 77 and KSS-KOR (Poland's Committee for Social SelfDefense and the Defense of Workers). Ideologically and in its performance in two languages, the production aligned these demands not only with national identity and human/civil rights but also with the rights of other peoples in the region. Goose 
on a String synthesized the specific national character of these demands with their universality, anticipating the "liberal nationalism" of Havel. ${ }^{55}$ The presentation of Czech national identity as a whole, in its ambivalence, warnings, and questioning, expressed a liberal form of nationalism, one less defined by place and ethnicity than shared values and (insofar as they support liberal values) traditions - a strong one of which, in the Czech case, is skepticism. In the year prior to the revolution, an authorial theatre invited Havel into this vision of nationalism, one that stressed the history and tradition of Czech national identity as based in and striving toward liberal values rather than a universalism toward which Czechs should aspire and which is inherent to them as persons (rather than as Czechs). ${ }^{56}$ At Goose on a String's prompting and as the result of authorial-dissident secret meetings that had begun in 1985, Havel wrote Tomorrow We'll Launch It (1988), which the company produced anonymously. Celebrating the independence of Czechoslovakia from the Austro-Hungarian Empire, it centered on the efforts of Alois Rašín, once sentenced to death by the Viennese government for high treason, to create an independent Czechoslovak state in 1918. While Masaryk negotiated from outside the country, Rašín was the principal exponent of a free Czechoslovakia within its borders, arranging secret meetings and coordinating "dissident" activities to bring about a peaceful revolution. Not only did it uncannily predict events in 1989, with Havel re-playing his own historical protagonist, but it underscored a development of the previous fifteen years, that the authorial theatres had become the nation's theatres while the stately National Theatre in Prague had become an acolyte of the state.

The paradox here resides not so much in the nomenclature of the National Theatre as in the status of studio theatres that functioned as organic national theatres, representatives of the views of the Czech people, and yet were also part of the state apparatus. Separated from the average Czech in many ways, dissidents in the 1970s remained largely unaware of developments in "official" culture that were inimical to official policies and ideology. Although Benda had spoken of developing parallel structures that could supplement "the generally beneficial and necessary functions that are missing in the existing structures, and where possible to use the existing structures, to humanise them," none of his examples come from "existing structures." ${ }^{57}$ Such binaries even cling to the thinking of researchers like John Glenn, who discusses the critical role of the theatres shortly before and during the revolution, but nonetheless defines civil society as "a sphere of self-organizing activity outside of and autonomous from the state. ${ }^{" 58}$ Czech reality was messier. Shortly after resuming attendance at authorial theatre productions in 1983, Havel penned an essay directed to his fellow dissidents. "Six Asides about Culture" sought to break down binaries and boundaries, to redefine the territory of the parallel polis by acknowledging the possibility of a "wholly new space between the two present cultures." He argues that the measure of a work's artistic power bears no relationship to the culture in which it originates: "If we do speak of 'two cultures', one official 
and one 'parallel', it does not mean ... that the one serves one set of political ideas and the second another set . . ., but refers solely to the external framework of culture." He sometimes discovered in the first (official) culture something that he would have expected in the second. Moreover, he asserts that the first culture is, ultimately, the "decisive sphere":

It will be in the "first" culture that the decision will be made about the future climate of our lives; through it our citizens will have the first genuine, wide-scale chance to stand up straight and liberate themselves. The "second" culture's relation to it will be analogous to that of a match to a glowing stove; without it, the fire might not have started at all, yet by itself it cannot heat the room. ${ }^{59}$

In an environment where independent organizations were suppressed, Havel sensed that civil society and the nation it represented functioned as "key symbolic operators, elements in ideological fields, rather than organizational realities." ${ }^{60}$ Such a view of civil society, which Charles Taylor defines as "a web of autonomous associations, independent of the state, which bind citizens together in matters of common concern, and by their existence or action could have an effect on public policy," allows us to see the nature of its formation in circumstances where its organizational manifestations are inhibited. ${ }^{61}$ If civil society and the nation could be said to have had a pre-1989 organizational home, however, the "Velvet" Revolution — during which Civic Forum's critical coordinating activity as well as the public forums that united public opinion were housed in theatre spaces - confirmed their residence in the authorial theatres. Recognizing that ideas, sentiments, and alliances were not the purview of one cultural context or another, Havel was able to realize that Czech civil society was not bound or defined by an "external framework." Similarly, Czech theatre and writer dissidents saw beyond the external frameworks of "indigenous" culture, national identity, and totalitarian insularity to concepts that crossed cultural borders. In their promiscuous, transcultural engagement with "foreign" ideas, they found parallels in their local cultural history. The significantly different relationship from writers that theatre artists necessarily bore to structural frameworks, however, conditioned the ways in which they expressed their dissenting ideas. Havel acknowledges that "in a totalitarian state" all theatre "media" (buildings and physical resources) "fall under state control." 62 For theatre, then, the question was never how one could continue outside the official structures, but how one could work within and negotiate the official structures in such a way that theatre with an independent life and voice could be produced. Authorial theatre artists, in 
this critical sense, unlike the dissident writers, occupied a position in relationship to power and its structures reflective of that of the average Czech. "The real sphere of potential politics in the post-totalitarian system is elsewhere" than the "hidden sphere," observed Havel, but lay "in the continuing and cruel tension between the complex demands of that system and the aims of life." ${ }^{\circ 3}$

Which set of dissenting thinkers originated a particular idea is ultimately less important than the realization that such ideas developed in different realms, with distinct strengths and effects, simultaneously early in the period and in dialogue later. Theatre addressed the existential, political, and social changes in its own distinct and dramaturgical "language," though its solutions complemented those of the writers. As a public art, theatre enabled a contained experience of civil society and community, and also one of freedom, solidarity, democracy, and national identity that the isolated dissidents' works could not match, and in this lay its attractive power as well as its ability to reach and affect large numbers of people. Czech audiences prior to 1989, experiencing within the performative context the possibility, perhaps even the utopia, of what their society and nation could be, would seem, ironically, to confirm the conclusion to which Karl Marx had once arrived, that "civil society is the true focal point, the theatre of all history." ${ }^{\prime 4}$

\section{Notes}

1. Barbara Falk, Dilemmas of Dissidence in East-Central Europe: Citizen Intellectuals and Philosopher Kings (Budapest: Central European U P, 2003) 2. Also see John K. Glenn's Framing Democracy: Civil Society and Civic Movements in Eastern Europe (Stanford: Stanford U P, 2001) chapters 1-2, 5-6 for an explanation of the role and significance of internal developments on the political changes of 1989.

2. Post-totalitarianism as defined by Václav Havel does not indicate a period that follows totalitarianism but a stage of totalitarianism distinct from earlier, classical dictatorships, which wielded power through a tangible, literal threat of violence. Post-totalitarianism gains historical legitimacy through a social movement and definable ideology, which has the benefit of creating unified belief but, for individuals, means "the consignment of reason and conscience to a higher authority" (Havel, "Power" 39 - cited below). In time, however, ideology devolves into the ritual of performing absent belief. While the traditional system necessarily left gaps for social, psychological, and physical expression of opposition, post-totalitarian approaches close many of these fissures through state ownership, central direction of the means of production, and absorption of social organizations, allowing the state to regulate the daily life of citizens. See Juan J. Linz, "Totalitarian and Authoritarian Regimes," Handbook of Political Science, eds. Fred I. Greenstein and Nelson Polsby, vol. 3 (Reading, MA: Addison-Wesley, 1975) 175-411 for more on the term.

3. Michael Walzer, "The Civil Society Argument," in Dimensions of Radical Democracy: Pluralism, Citizenship, Community, ed. Chantal Mouffe (London: Verso, 1992) 89.

4. Robin H. E. Shepherd, Czechoslovakia: The Velvet Revolution and Beyond (New York: St. Martin's, 2000) 2.

5. Kazimierz Braun, A History of Polish Theater, 1939-1989: Spheres of Captivity and Freedom (Westport, CT: Greenwood P, 1996) 105-15.

6. The best known practitioner of apartment theatre was National Theatre actress Vlasta Chramostová. See Karel Kyncl, "A Censored Life: The Story of Vlasta Chramostová and Her Living Room Theatre in Prague," Index on Censorship 14.1 (1 Feb. 1985): 37-42.

7. Shepherd, Czechoslovakia 2.

8. Falk, Dilemmas of Dissidence 145, italics in original. See Jiřina Šiklová's "The 'Gray Zone' and the Future of Dissent in Czechoslovakia (1989): Epilogue (1990)," Goodbye Samizdat: Twenty Years of Czechoslovak Underground Writing, ed. Marketa Goetz-Stankiewicz (Evanston: Northwestern 
U P, 1992) 181-92 for more on the significance of the gray zone.

9. Marketa Goetz-Stankiewicz, The Silenced Theatre: Czech Playwrights without a Stage (Toronto: U of Toronto P, 1979).

10. In a speech given significantly in Prague in April of 1987, Gorbachev presented the idea of his belief in a "common European home," also expressed in his book Perestroika: New Thinking for our Country and the World published that same year (New York: Harper and Row). In it he condemned "the artificiality and temporariness of the bloc-to-bloc confrontation and archaic nature of the "iron curtain" (194-5). He also indicated a dubious change in Soviet policy when he stated that "we have also become convinced that there is no model of socialism to be emulated by everyone" (qtd. in The Velvet Revolution: Czechoslovakia, 1988-1997 by Bernard Wheaton and Zdeněk Kavan (Boulder: Westview P, 1992) 17.

11. Falk, Dilemmas of Dissidence 7; Petr Oslzlý, "Onstage with the Velvet Revolution," TDR 34.3 (Fall 1990): 101.

12. Although Poland's Adam Michnik first articulated that society rather than the state was the target of reform in his 1976 essay "A New Evolutionism," Czechoslovakia's Václav Havel in "The Power of the Powerless" (1978) examined in detail how the change in an individual's thinking and consequent behavior created a challenge to the post-totalitarian system. The concept of a bacteriological weapon that could "disarm an entire division" is Havel's and one that he uses specifically to describe the power of truth or "living in truth." As the parallel poleis, with the alternative theatres among them, were "islands of freedom" that allowed individuals as a collective to live in truth, as I argue below, they themselves multiplied the bacteriological effect. See Havel, "The Power of the Powerless" trans. Paul Wilson, Václav Havel or Living in Truth, ed. Jan Vladislav (London: Faber and Faber, 1986) 58.

13. Antonio Gramsci, Selections from the Prison Notebooks of Antonio Gramsci, eds. and trans. Quintin Hoare and Geoffrey Nowell Smith (London: Electric Book Co., 2001) 131.

14. Anonymous, "Anonymous," Civic Freedom in Central Europe: Voices from Czechoslovakia, ed. H. Gordon Skilling (London: Macmillan, 1991) 45.

15. Josef Kovalčuk, Autorské divadlo 70.let (vztah scénáře inscenace) (Prague: Ústav pro kulturně výchovnou činnost, 1982) 8.

16. Alan Read, Theatre \& Everyday Life: An Ethics of Performance (London: Routledge, 1995) 95.

17. Peter Scherhaufer, "Divadlo na provázku—model 1970," Divadlo 13.2 (1970): 71-2.

18. György Konrád, Antipolitics: An Essay, trans. Richard E. Allen (San Diego: Harcourt Brace, Jovanovich, 1984) 74.

19. Dennis Christilles and Delbert Unruh, "The Semiotics of Action Design," Theatre Topics 6.2 (1996): 121. The global influence of Action Design attests to the applicability of authorial theatre principles outside Czech or overtly authoritarian contexts. The interwar Czech theorists who were formative to the later development of Action Design (Christilles 140 n. 2) developed their ideas in large part in response to the theatre artists who had formed the roots of authorial theatre. Also, the designers whose works Christilles and Unruh believe "best exemplify the principles that animate Action Design" and are perhaps its most influential early proponents, Jaroslav Malina and Jozef Ciller, developed their ideas and approaches for the earliest two authorial theatres studied here, Studio Ypsilon and Theatre Goose on a String, respectively. The authorial approach crystallized their interests into what was later identified as Action Design. Therefore, when Christilles and Unruh explain that "Action Design, a scenographic methodology with its formative roots in the former Czechoslovakia, is, in fact, an approach to all aspects of theatre production" (121), they misidentify a part of the elephant for the whole. Authorial theatre is the approach to theatre production to which they refer, of which Action Design is a component that reflects and contains elements of the entirety.

20. Jan Schmid, Zpuisob myšleni a přemýšlení: Interni materiál pro tvưrčí besedy Dílny Studia $Y$, ed. Jan Kolař (Prague: Svaz českých dramatických umělců, 1984) 3.

21. Milan Šmečka, The Restoration of Order: The Normalization of Czechoslovakia, 1969-1976, trans. A. G. Brain (London: Verso, 1984) 122.

22. Zdeněk Hořínek, "The Possibilities of Theatrical Montage (Successive and Simultaneous)," Theatre Survey 36.1 (May 1995): 79-80.

23. "Charter 77," Index on Censorship 6.3 (1977): 33.

24. Hoř́nek, "The Possibilities of Theatrical Montage" 78, 81, 82.

25. Sergei Eisenstein, "The Montage of Attractions," Eisenstein at Work, ed. Jay Leyda and Zina Voynow (New York: Pantheon, 1982) 17. "Stone" theatre was the name Czechs commonly gave to traditional, often large theatres meant to reflect not only their building material but their internal petrifaction. The NEP was Lenin's New Economic Policy, 1921-9, which Stalin ended. The authorial theatres also produced a number of plays from this artistically liberated era, and Goose on a String was inspired by Meyerhold's work and ideas. 
26. Vladimír Jindra, "Notes on the Works of František Tröster," Interscena 2.2 (Prague: Prague Theatre Institute, 1980) 67. Also cited in Christilles and Unruh, "The Semiotics of Action Design" 122.

27. Falk, Dilemmas of Dissidence 215.

28. Martin Palouš, "The Parallel Polis after Twelve Years," Uncaptive Minds 2.5 (1989): 39; Falk, Dilemmas of Dissidence 245-6.

29. Václav Benda, "The Parallel Polis," Civic Freedom in Central Europe: Voices from Czechoslovakia, ed. H. Gordon Skilling and Paul Wilson (London: Macmillan, 1991) 37.

30. Falk, Dilemmas of Dissidence 246.

31. Václav Havel, "The Power of the Powerless," in Vladislav, Václav Havel or Living in Truth 62.

32. Jan Dvořák, Divadlo v akci (Prague: Panorama, 1988) 34-5.

33. Havel, "Power of the Powerless" 59, 62.

34. Václav Havel, "Politics and Conscience," in Vladislav, Václav Havel or Living in Truth 137. Labyrinth's original opening was in Copenhagen in 1981, but officials would not permit its Czechoslovak showing until 1983.

35. 142, 153. Although Havel distinguishes the origins of such systems as based in rationalistic conceptions of the universe, he perceives that in their self-perpetuating tendency divorced from human control a dangerous and inhuman irrationality, since power comes to serve power rather than persons or even ideas.

36. Václav Havel, "Dear Dr. Husak, "Open Letters" Selected Writings, 1965-1990, trans. and ed. Paul Wilson, et al. (New York: Vintage, 1992) 68; "Politics and Conscience" 138, 154.

37. Dilemmas of Dissidence, 344, 305-6.

38. Christilles and Unruh, "Semiotics of Action Design" 122-3.

39. Vlasta Gallerová, "Několik poznámek ke scénografii Hanáčkého divadla," Pokus o zachycení specifiky tvorby, ed. Vlasta Gallerová (Prague: Svaz českých dramatických umělci, 1985) 100.

40. Martin Heidegger, Being and Time: A Translation of Sein und Zeit, trans. Joan Stambaugh (Albany: SUNY P, 1996) 248, italics in original.

41. 248 , my italics.

42. Falk, Dilemmas of Dissidence 245.

43. Havel, "The Power of the Powerless" 44.

44. $56-57$.

45. Šimečka, Restoration of Power 122.

46. Havel, "The Power of the Powerless" 75.

47. Václav Havel, “An Anatomy of Reticence," trans. E. Kohák, in Vladislav, Václav Havel or Living in Truth 165, 188.

48. Falk, Dilemmas of Dissidence xxvi.

49. Stefan Auer, Liberal Nationalism in Central Europe (London: Routledge, 2004) 22.

50. Falk, Dilemmas of Dissidence, 244-5.

51. See, for example, Falk, Dilemmas of Dissidence, 364; Paul Berman, "The Philosopher King is Mortal," The New York Times Magazine 11 May 1997: 32-59; Auer, Liberal Nationalism 120; or the 2007 University of Toronto symposium on the "Life and Work of Václav Havel: Citizen Intellectual and Philosopher King."

52. Václav Benda, "The Parallel Polis" 36; Holy, The Little Czech 42.

53. Holy, The Little Czech 41, 33-5, 48.

54. Czech history was also activated and exhumed in works from the interwar period that authorial theatres remounted. Although they offered images of Czech national identity, their greater significance lay in their reclamation of pre- and interwar theatre artists and styles. Their approaches made audiences aware that the authorial theatres were carrying on the indigenous "national" traditions of E.F. Burian, Voskovec and Werich, Seven of Hearts, the poetists, and Jindřich Honzl, thus denying through omission Russian-associated approaches to realism, whether socialist or Stanislavskian. The ideological significance of "experimental" interwar approaches found in the underlying meanings of theatrical "authorship" examined above (pluralism, democracy, freedom, equality, etc.) was not lost on audiences.

55. See Auer, Liberal Nationalism 19, 171. Chapters one and four discuss liberal nationalism and its relationship to Czech history and conceptions of national identity.

56. Czech "independent" historiography in samizdat had resumed a parallel project of reconsidering the Czech national past. Following such work in the 1960s, it would not be until after Charter 77 that historians would catch "a second breath." Even then, as H. Gordon Skilling notes, "their audience was small - a few of their fellow historians and some interested scholars at home and abroad" (Samizdat and an Independent Society in Central and Eastern Europe 107).

57. Benda, "The Parallel Polis" 36, 37. My emphasis. 
58. John K. Glenn, Framing Democracy: Civil Society and Civic Movements in Eastern Europe (Stanford: Stanford U P, 2001) 194.

59. Václav Havel, "Six Asides about Culture" trans. E. Kohák, in Vladislav, Václav Havel or Living in Truth 124, 132, 134.

60. Katherine Vedery, What Was Socialism, and What Comes Next? (Princeton: Princeton U P, 1996) 105.

61. Charles Taylor, "Modes of Civil Society," Public Culture 3.1 (Fall 1990): 96. Also cited in Falk, Dilemmas of Dissidence 315. By centering on associations rather than organizations, Taylor's insight highlights a weakness of the Gramscian schema of civil society composed of two aspects, an organizational/institutional realm and what Pelczynski follows Tocqueville in calling “"political society,' existing outside and in opposition to the state and ... reflect[ing] the critical concern over all kinds of general issues kept off the public agenda of the class-dominated state system." See Z.A. Palczynski, "Solidarity and the Rebirth of Civil Society in Poland, 1976-1981," Civil Society and the State: New European Perspectives, ed. John Keane (New York: Verso, 1988) 368.

62. Havel, "Six Asides about Culture" 127.

63. Havel, "Power of the Powerless" 69-70.

64. Karl Marx, The German Ideology. vol. 1, Karl Marx and Friedrich Engels, Selected Works, 3 vols. (Moscow: Progress, 1973) 76. 
